\title{
Ethoglucid in Treatment of Inoperable Lung Cancer
}

\author{
A. W. LEES, ${ }^{*}$ M.D., F.R.C.P.ED., F.R.C.P.S.GLASG., D.P.H.
}

Brit. med. F., 1965, 1, 230-231

Ethoglucid (triethyleneglycol diglycidyl ether; Epodyl), a new cytotoxic agent, was used in the treatment of cases of inoperable lung cancer, and the results are compared with those of mustine (methyl bis [beta-chloroethyl] amine).

\section{Method}

Patients with proved inoperable lung cancer who had dyspnoea, dysphagia, or the mediastinal-compression syndrome - that is, patients in whom benefit would be easy to assesswere allocated at random to ethoglucid or mustine treatment. The severity of symptoms was assessed, and a chest $x$-ray film was taken just before treatment was started and weekly for four weeks thereafter. White blood cell counts, platelet counts, and haemoglobin estimations were routinely performed before the start of treatment and weekly (or oftener if indicated) for four weeks thereafter.

Ethoglucid or mustine was given in a single intravenous dose. To minimize nausea and vomiting meclozine $50 \mathrm{mg}$. and pyridoxine $50 \mathrm{mg}$. were given half an hour before the drug was injected. The dose of ethoglucid was $250 \mathrm{mg}$. $/ \mathrm{kg}$. body weight for lean active subjects, and $200 \mathrm{mg} . / \mathrm{kg}$. for fat or feeble subjects. The dose of mustine was $0.5 \mathrm{mg}$. $/ \mathrm{kg}$.

\section{Results}

Two severely ill patients (one on ethoglucid and one on mustine treatment) died within a week of receiving the drug and were excluded from the study. The results of 31 patients in the ethoglucid series and 31 in the mustine series were available for comparison.

Symptomatic Relief.-The extent of symptomatic relief was classified as pronounced, moderate, slight, or none. The results are shown in Table I. There was no significant difference between the two series: $24(77 \%)$ of the ethoglucid patients and

TABLE I.-Symptomatic Relief

\begin{tabular}{ll|c|c|c|c|c}
\hline \multirow{2}{*}{ Agent } & & \multicolumn{4}{|c|}{ Extent of Relief } & Total \\
\cline { 2 - 5 } & & Pronounced & Moderate & Slight & None & \\
\hline Ethoglucid & $\ldots$ & 12 & 12 & 4 & 3 & 31 \\
Mustine.. & $\cdots$ & 13 & 13 & 3 & 2 & 31 \\
\hline
\end{tabular}

TABLE II.-Duration of Symptomatic Relief

\begin{tabular}{|c|c|c|c|c|c|c|}
\hline \multirow{2}{*}{ Agent } & & \multicolumn{4}{|c|}{ Weeks } & \multirow{2}{*}{ Total } \\
\hline & & 1 & 2 & 3 & $4+$ & \\
\hline $\begin{array}{ll}\text { Ethoglucid } & \ldots \\
\text { Mustine } & \ldots\end{array}$ & $\because$ & & $\begin{array}{l}7 \\
2\end{array}$ & $\begin{array}{l}8 \\
4\end{array}$ & $\begin{array}{l}13 \\
23\end{array}$ & $\begin{array}{l}28 \\
29\end{array}$ \\
\hline
\end{tabular}

$26(84 \%)$ of the mustine patients received pronounced or moderate symptomatic relief. Symptomatic improvement, when it occurred, began within a week of drug administration, but the subsequent inevitable deterioration sometimes appeared within the four-week observation period. Table II shows the duration of maximum benefit in weeks. Within the four-week observation period deterioration had occurred in $18(58 \%)$ of

* Consultant Chest Physician, Ruchill Hospital, Glasgow. the ethoglucid patients and in $8(26 \%)$ of the mustine patients.

Radiological Response.-Radiological improvement was classed as pronounced, moderate, slight, or none, and the findings are shown in Table III. Substantial (pronounced or moderate) improvement occurred in $5(16 \%)$ of the ethoglucid cases and in $16(51 \%)$ of the mustine cases.

\begin{tabular}{|c|c|c|c|c|c|c|}
\hline \multirow{2}{*}{\multicolumn{2}{|c|}{ Agent }} & \multicolumn{4}{|c|}{ Degree of Improvement } & \multirow{2}{*}{ Total } \\
\hline & & Pronounced & Moderate & Slight & None & \\
\hline $\begin{array}{l}\text { Ethoglucid } \\
\text { Mustine .. }\end{array}$ & $\because$ & $\begin{array}{l}3 \\
8\end{array}$ & $\begin{array}{l}2 \\
8\end{array}$ & $\begin{array}{l}1 \\
4\end{array}$ & $\begin{array}{l}25 \\
11\end{array}$ & $\begin{array}{l}31 \\
31\end{array}$ \\
\hline
\end{tabular}

Early Side-effects.-The severity of nausea or vomiting (if any) after drug administration was noted. Of the 31 ethoglucid cases side-effects were pronounced in 2 , moderate in 6 , slight in 13 , and absent in 10 . Of the 31 mustine cases they were pronounced in 3 , moderate in 7 , slight in 13 , and absent in 8 . A further side-effect was transient loss of consciousness, which occurred in two patients after ethoglucid administration and was accompanied by convulsions in one.

Late Side-effects. - There were no side-effects from haemopoietic-tissue depression in either series. In 22 cases in each series the white blood cell count was significantly lower 14 days after drug administration than it was before, but in only one instance in each series did the count fall below $1,000 / \mathrm{c} . \mathrm{mm}$. Platelet counts tended to parallel white blood cell counts. White blood cell and platelet counts in all instances reached pretreatment level in three to four weeks. There was little change in haemoglobin levels in either series.

\section{Discussion}

This investigation suggests that ethoglucid in a dosage of 200$250 \mathrm{mg}$. $/ \mathrm{kg}$. has a useful palliative action in cases of inoperable lung cancer, but that it is less effective than intravenous mustine in a dosage of $0.5 \mathrm{mg} . / \mathrm{kg}$. The immediate symptomatic relief given by ethoglucid was comparable to that given by mustine, but benefit was more ephemeral. The maximum improvement achieved was maintained to the end of the four-week observation period in only $13(46 \%)$ of the 28 ethoglucid patients in whom benefit had been noted compared with 23 (79\%) of the 29 who had benefited from mustine. Moreover, radiological improvement of some degree occurred in only $6(19 \%)$ of the ethoglucid patients compared with $20(64 \%)$ of the mustine patients. It should be mentioned that the distribution of cell types was comparable in the two series.

The transient loss of consciousness in the two patients immediately after ethoglucid (accompanied by convulsions in one) was attributable to the hypotension which may follow administration of the drug. This side-effect would not be a serious drawback if nausea and vomiting were significantly less than with mustine, but unfortunately this did not prove to be the case. Serious side-effects from bone-marrow depression from ethoglucid were not encountered, but judging from the experience of Bond et al. (1964), who used the same dosage in cases of malignancy (not of the bronchus), it would not be safe to give more. In general, therefore, ethoglucid given systemically seems 
inferior to mustine in the treatment of inoperable cases of lung cancer, though Bond et al. (1964) suggest that owing to a sensory neurotoxic effect ethoglucid may be of special value for relieving pain. It may also prove to have advantages when given intra-arterially (Bond et al., 1964 ; Bailey et al., 1964).

\section{Summary}

Patients with inoperable lung cancer who had dyspnoea, dysphagia, or mediastinal-compression syndrome were allocated at random to treatment with ethoglucid $200-250 \mathrm{mg} . / \mathrm{kg}$. in a single intravenous dose or mustine $0.5 \mathrm{mg}$. $/ \mathrm{kg}$. similarly given.
Thirty-one patients were treated with each agent. Ethoglucid produced much the same immediate symptomatic relief as mustine, but benefit was more ephemeral and radiological improvement less frequent. Immediate reactions from the drugs were of comparable frequency and severity and neither drug caused side-effects from bone-marrow depression. Intravenous ethoglucid (200-250 mg./kg.) was therefore less effective than intravenous mustine $(0.5 \mathrm{mg} . / \mathrm{kg}$. $)$, and had no compensating advantages.

\section{REFERENCES}

Bailey, I. C., Taylor, A. R., and Grebbell, F. S. (1964). Brit. med. F., 1,

Bond, M. R., Clarke, S. D., and Neal, F. E. (1964). Ibid., 1, 951.

\title{
Use of a Patient-triggered Intermittent Positive-pressure Respirator in Respiratory Paralysis
}

\author{
N. P. S. GUNARATNA,* M.B., B.S., D.C.H.
}

Brit. med. F., 1965, 1, 231-233

The current practice in most artificial respiration units in this country is to use tracheostomy and intermittent positivepressure ventilation (I.P.P.V.) to provide controlled ventilation (Smith et al., 1954). This method is relatively easy to use in patients with complete respiratory paralysis. However, in partial respiratory paralysis, when the patient requires only assistance to spontaneous respiratory efforts, the problem of providing this assistance in synchrony with the patient's own efforts is considerable. Such patients tend to breathe against the rhythm of the respirator and increase their respiratory distress, necessitating sedation or curarization procedures which are not always desirable. The problem was overcome by the use of a patient-triggered respirator in treating two patients at the Western Hospital recently. This paper reports the use of this machine, an Air Shields Electronic Respirator, ${ }^{1}$ a time-cycled, volume-limited instrument which requires the patient to displace only $4 \mathrm{ml}$. of air to trigger the assistor.

\section{Description of the Respirator}

The illustrations show a photograph (Fig. 1) and schematic drawings (Figs. 2 and 3 ) of the respirator.

When the unit is operating, a motor blower (B in Fig. 2) draws air into the blower housing. A portion of this air provides cooling for the motor and warms the water in the humidity chamber (P). The remainder is delivered to the bellows chamber $(N)$ surrounding the bellows $(M)$, causing the bellows to contract and set up a positive ventilatory flow. The flow from the blower to the bellows chamber is controlled by a solenoid (C) and a flow valve (D).

During the inspiratory phase (Fig. 2) the positive pressure acts on the outside of the bellows, causing it to rise and displace the air contained inside through the humidity chamber and delivery tube to the patient at $T$. The air in the bellows is not mixed with the air from the motor blower

\footnotetext{
* Registrar, Artificial Respiration Unit, Western Hospital, London.
}

${ }^{1}$ The Air Shields Electronic Respirator by Air Shields Incorporated of U.S.A. was kindly lent to us, and the schematic drawings and photograph were supplied, by their subsidiary in the United Kingdom. but is room air drawn into the bellows through the filter (V). During the expiratory phase the expired air passes through the exhalation valve $(S)$. As the weighted bellows falls it is refilled with filtered room air.

The respirator, as mentioned above, is a time-cycled unit with independent adjustment of the inspiratory and expiratory phases. For any given setting of the inspiratory phase the actual volume delivered by the respirator can be varied by means of the flow valve. The flow can be adjusted from almost zero to 100 litres per minute.

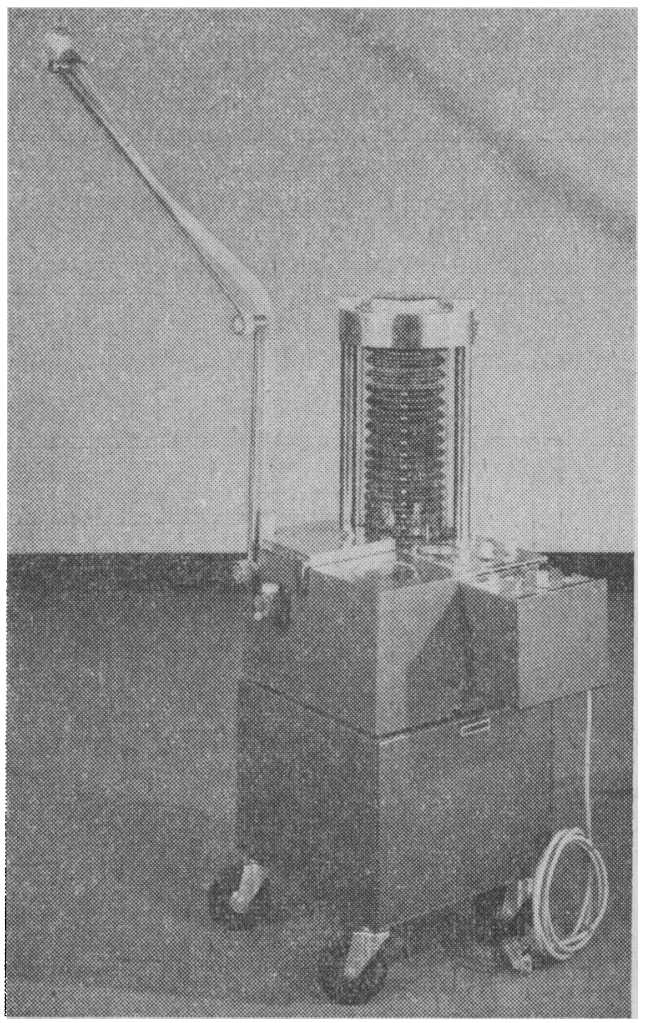

FIG. 1.-The respirator. 